\title{
Akustik kanallarla ötürülən nitq informasiyasının təhlükəsizliyinin bəzi vibroakustik mühafizə metodları haqqinda
}

\author{
Bikəs Ağayev ${ }^{1}$, Tərlan Oliyev ${ }^{2}$, Kövsər Oliyeva $^{3}$, Məleykə İbişova ${ }^{4}$ \\ AMEA İnformasiya Texnologiyaları İnstitutu, Bakı, Azərbaycan \\ 1,2,3,4depart6@iit.sciense.az
}

\begin{abstract}
Xülasə- Məqalədə otaq şəraitində aparılan və müəyyən məxfiliyə malik danışıqlar prosesinin nitq informasiyasının təhlükəsizlik məsələləri araşdırılır. Akustik kanallarla ötürülən nitq informasiyasının iştirakçılar tərəfindən diktofonla gizli yazılması vo otaqdan kənara sizan vibroakustik siqnallarm ilkin vəziyyətinin əldə edilməsinə qarşı mühafizə metodlarına baxılır. Baxılan hallar üçün təşkilatın informasiya təhlükəsizliyi siyasətinin müəyyənləșdirilməsi istiqamətində təkliflər verilir.
\end{abstract}

Açar sözlor- nitq informasiyası; akustik yayılma kanalı; danışıqların gizli yazılması; vibroakustik sızma kanalları; informasiya tohlükosizliyi; nitq informasiyasının mühafizosi

\section{GİRIŞ}

İnsanlar arasında ünsiyyət əsas etibarilə danıșıqlar, nitq informasiyası vasitəsilə həyata keçirilir. $\mathrm{Bu}$ ünsiyyət istər birbaşa danışıqlar, yəni akustik kanallarla, istərsə də texniki vasitələrdən istifadə etməklə elektromaqnit, elektroakustik, vibroakustik, elektrooptik və s. kanallarla həyata keçirilə bilər. $\mathrm{Bu}$ danışıqların məzmununda adi məişət məsələlərinə aid məlumatlardan tutmuş şəxslərin fərdi məlumatları, təşkilatın maliyyə və kommersiya sirləri, elmi tədqiqatların nəticələri, hərbi və dövlət sirləri və s. yayılması arzu olunmayan və ya qanunla qadağan olunmuş məlumatlar ola bilər. Burada danışıqların məzmununa münasibətdə maraqları əks olan iki tərəf var: məlumatların digərlərinin əlinə keçməməsində maraqlı olan danıșıq iștirakçıları və bu danışıqları əldə etməklə ondan qərəzli məqsədlərlə istifadə etməyə çalışan digər şəxslər. Texnika və texnologiyaların hazırkı inkişaf səviyyəsində hər iki tərəfin maraqlarını təmin etməyə imkan yaradan çoxlu sayda mükəmməl texnologiyalar, texniki vasitələr, metodlar yaradılsa da onların tətbiqi zamanı bir sıra çətinliklərlə üzləşirlər. Bu ilk növbədə təşkilatın informasiya təhlükəsizliyi siyasətinin, təhlükəsizliyi təmin edən mühafizə taktikasının düzgün formalaşdırılmasından, o cümlədən mühafizə məqsədilə düzgün texniki həll variantının seçilməsindən asılıdır. Digər tərəfdən təşkilat rəhbərliyinin informasiya mühafizəsi problemləri və onların həlli yolları haqqında bilik səviyyəsi və məsələyə münasibəti, təşkilatın maliyyə imkanları və $\mathrm{s}$. informasiya təhlükəsizliyi tədbirlərinin həyata keçirilməsinə təsir edən amillərdəndir.
Göründüyü kimi nitq informasiyasının təhlükəsizliyinin təmin edilməsi hər bir fərd, təşkilat və dövlət üçün aktual və əhəmiyyətli məsələdir.

Məqalədə yalnız otaq şəraitində aparılan danışıqların akustik kanalla ötürülməsi halında nitq informasiya axınının təhlükəsizliyi məsələlərinə baxılmışdır. Burada otaq dedikdə təşkilat rəhbərinin iş otağı, məşvərət otağı, strateji fəaliyyət sahələrinin, xüsusi xidmət sahələrinin, idarəetmə orqanları kimi mühüm qurumların iş yerləri, əraziləri ola bilər.

\section{SЭS VӘ KÜY HAQQINDA QISA ŞӘRH}

Nitq informasiyasının təhlükəsizliyinin təşkilinə aidiyyatı olan hər bir şəxs səsin mahiyyəti, yayılması və qəbulu haqqında minimal məlumatlara malik olmalıdır. Səs havada (qazvari mühitdə) bərk cisimlərdə və mayelərdə dalğalar şəklində yayılan elastik mühitin hissəciklərinin rəqsi hərəkəti nəticəsində yaranır. Səs, o cümlədən nitq dalğaları enerji daşımaqla qarşılaşdı̆̆ bu təzyiqin qiyməti yayılma mühitinin təzyiqindən, məsələn atmosfer təzyiqindən böyükdürsə müəyyən intensivliyə malik səs yaradır. Bu maneə qulaq pərdəsidirsə biz, dalğa enerjisinin yaratdığı təzyiqi subyektiv olaraq səs hissi kimi qəbul edirik. $\mathrm{Bu}$ səs gücü (intensivliyi) və tezliyi ilə xarakterizə edilir. Otaqda danışıqların, hərəkət edən cisimlərin və s. mənbələrin yaratdığı səs dalğalarının enerjisinin bir hissəsi istənilən maneədən əks edərək ətrafa yayılır, bir hissəsi maneə tərəfindən udulur, digər hissəsi isə maneədən keçərək əks tərəfə yayılır (şəkil 1).

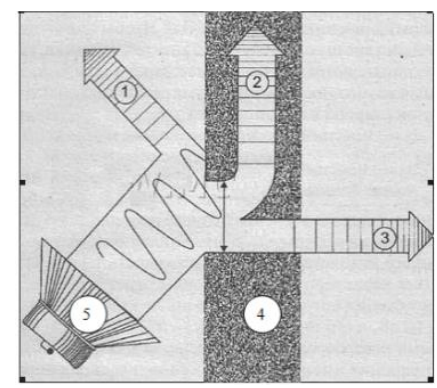

Şəkil 1. Səs dalğalarının maneə ilə qarşılıqlı təsiri

1-əks edən, 2-udulan, 3-nüfuz edən hissələr, 4-maneə (divar), 5-səs mənbəyi 


\section{“Informasiya tohlükosizliyinin aktual multidissiplinar elmi-praktiki problemlori” \\ V respublika konfransı, 29 noyabr 2019-cu il}

İnsan qulağının eşitməsi üçün səsin qulaqda yaratdığı təzyiqin səviyyəsi nisbi qiymətlərdə sıfir desibeldən (db) və ya mütləq qiymətlərdə $2 \cdot 10^{-5}$ paskaldan $(\mathrm{Pa})$ böyük olmalıdır. Qeyd edək ki, müəyyən şərait üçün normativ sənədlərlə müəyyənləşdirilmiş həddən yüksəək intensivliyə malik səslər küy adlanır. Yuxarıda qeyd edilən bu səviyyə sağlam qulağın eşitdiyi ən zəif səsi xarakterizə edir (eşitmə həddi). Digər tərəfdən səviyyəsi $120 \mathrm{db}$ (və ya 1 pa) olan küylər qulağımızda ağrı hissi yaradır və ağrı həddi adlanır. $150 \mathrm{db}$ səviyyəli küylər qulaq pərdəsini deşir, 180-200 db isə insana öldürücü təsir edir. Normal ucalıqda aparılan danışıqların yaratdığ səslər 30-40 db intensivliyinə uyğun gəlir [1].

\section{NITQ İNFORMASIYASININ MÜHAFIZӘ METODLARI HAQQINDA}

Otaq şəraitində aparılan danışıqların akustik kanallarla ötürülməsi prosesində nitq informasiysıanın otaqdan xaricdə gizli əldə edilməsi və bu hala qarşı bəzi mühafizə tədbirlərini nəzərdən keçirək.

İlk növbədə qeyd edilməlidir ki, informasiya təhlükəsizliyi və məlumatların, o cümlədən fərdi məlumatların əldə edilməsi məsələləri milli qanunvericiliklə tənzimlənir. "AR-in Konstitusiya Qanunu"-na görə şəxsin razılığı olmadan və ya xəbərdar edilmədən onun danışıqlarının yazılması, foto, video çəkilişlərinin aparılması qadağandır (xüsusi hallar istisna olmaqla). Bu, məxfi və dövlət sirri daşıyan məlumatlara da şamil edilir. "Dövlət sirri haqqında" AR Qanunu dövlət sirri təşkil edən məlumatlarını üç məxfilik dərəcəsi ilə: xüsusi əhəmiyyətli, məxfi və tam məxfi kimi müəyyənləşdirir (maddə 7) və dövlət sirrinə aid edilən məlumatların qanunla müəyyən edilən təsnifatını təsbit edir (maddə 4). Qanunla belə məlumatların yayılması və qorunması məsuliyyəti vəzifəli şəxslərin, o cümlədən elmi tədqiqat müəssisələrinin rəhbərliyinin üzərinə qoyulur. Məsul şəxslər məxfiliyin pozulmasına görə qanunvericiliyə müvafiq olaraq cinayət, mülki-hüquq və ya inzibati məsuliyyət daşıyırlar (maddə 28) [2].

Şəkil 1-dən göründüyü kimi danışıqlardan yaranan səs rəqsləri dalğalarının bir hissəsi otağın bir çox konstruktiv inşaat elementlərindən nüfuz edərək xaricə yayıla və adi dinləmə yolu ilə əldə edilə bilər. Bu halda pəncərələr (xüsusilə açıq halda), qeyri-metal materiallardan hazırlanmış qapılar, hava tənzimləyici nəfəsciklər, tavan və döşəmə, eləcə də qaz, su, otağı qızdıran isitmə borularının, elektrik kommunikasiya xətlərinin divarlardan keçid yerlərində yaranmış boşluqlar və $\mathrm{s}$. nüfuzedici tərkibin sızma kanalı rolunu oynaya bilər.

Qeyd edək ki, hal-hazırda nitq informasiyasının istər akustik, istərsə də yuxarıda qeyd edilən digər texniki kanallardan icazəsiz əldə edilməsinə qarşı çoxsaylı mühafizə vasitələri mövcuddur. Qorunan danışıqların məxfilik statusundan, otaqların inşa konstruksiyasından, təşkilatın maliyyə imkanlarından və s. amillərdən asılı olaraq qiyməti və funksional imkanları kəskin fərqlənən çox sadə və ucuz, eləcə də xüsusi təyinatlı mürəkkəb və baha olan texniki vasitələrdən istifadə edilə bilər.
$\mathrm{Bu}$ məqsədlə istifadə edilən ən sadə mühafizə metodlarından biri danışı mühitinin akustik maneə siqnalları ilə küyləndirilməsidir. Bu halda danışıqlarla eyni vaxtda musiqinin, radio-televiziya verilişlərinin səsləndirilməsindən istifadə etmək olar. Belə ki, qulaq, maneə yaradan müxtəlif səs axınlarından faydalı nitqi seçmək kimi psixi-akustik xüsusiyyətə malikdir. Bu zaman kənar səslərlə qarışmış nitq dalğaları otaqdan kənara yayılsa və eşidilsə də anlaşılmaz olur. Metodun çatışmayan cəhəti kənar səslər fonunda danışıqların dərk edilməsinin çətinləşməsi, iştirakçılarda müəyyən inamsızlıq və yorğunluq hissinin yaranmasıdır. Digər variantda nitq rəqsləri enerjisinin nüfuzedici tərkibinin azaldılması məqsədilə otağın bütün səthinin səsuducu materiallarla üzlənməsidir. Bu məqsədlə səsuducu əmsalı böyük olan mineral pambıq, şüşəlifli və bazalt əsaslı materiallardan, köpükləndirilmiş poliamiddən (paralondan) və s. inşaat üzlük materiallarından istifadə etmək olar. Tavan və döşəmədən xaricə nüfuz edən səs dalğalarını zəiflətmək üçün asma tavan və ikinci qat döşəmə qurmaq olar. Bu halda nüfuzedici tərkibin zəiflədilməsi qeyd edilən maneələrdə səs enerjisinin bir hissəsinin udulması (maneələrin daxilində istilik enerjisinə çevrilməsi) hesabına baş verir.

Otağın konstruktiv elementlərində akustik səs dalğalarının yaratdığı vibrasiyaların xaricdən qəbul edilməsini aradan qaldırmaq üçün xüsusi texniki vasitələrdən istifadə etmək lazım gəlir. Məsələ ondadır ki, danışıqlardan yaranan akustik dalğalar otaq daxilindəki kommunikasiya xətlərində və otağın digər konstruktiv elementlərində (divarlar, tavan, döşəmə, pəncərə, qap1 və s.) nitq siqnallarının amplitudasına uyğun vibrasiya yaradır. Bu siqnallar nə qədər zəif olsa da qonşu otaqlardan, divarların xarici səthlərindən xüsusi qurğular vasitəsilə qəbul edilərək ilkin səs siqnallarının bərpa edilməsi üçün istifadə edilə bilər [3]. Bu, xüsusilə pəncərə şüşələrinə, polad borulara və divarlara aiddir. İnformasiyanın bu vibrokanallardan sızmasının qarşısını almaq üçün vibroküyləmə yaradan qurğulardan istifado edilir: qurğular eşidilən səs diapazonu tezliklərində vibrasiya rəqsləri generasiya edərək qeyd olunan konstruktiv elementlərə nüfuz etdirilir. Bu halda vibrasiyanın həmin elementlərdə yaratdığı rəqslər nitq rəqsləri ilə qarışaraq bədniyyətlinin əldə etdiyi siqnallardan nitq informasiyasını sintez etmək imkanını aradan qaldırır. Bu məqsədlə qurğunun generasiya etdiyi siqnal konstruksiyalara bərkidilmiş elektrik vibratorlarına verilir və onları müəyyən intensivlikdə rəqsə gətirir. Şəkil 2-də "Sonata-AB" markalı vibroküyləyicinin bir neçə tətbiq variantı göstərilmişdir [4].

a)

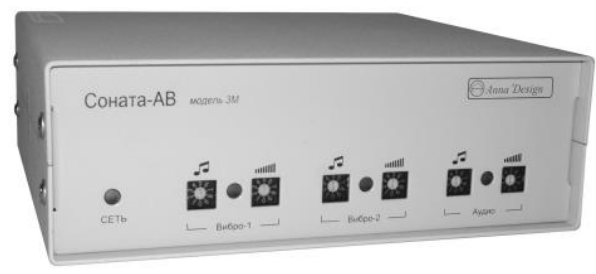




\section{“Informasiya tohlükosizliyinin aktual multidissiplinar elmi-praktiki problemlori” V respublika konfransı, 29 noyabr 2019-cu il}
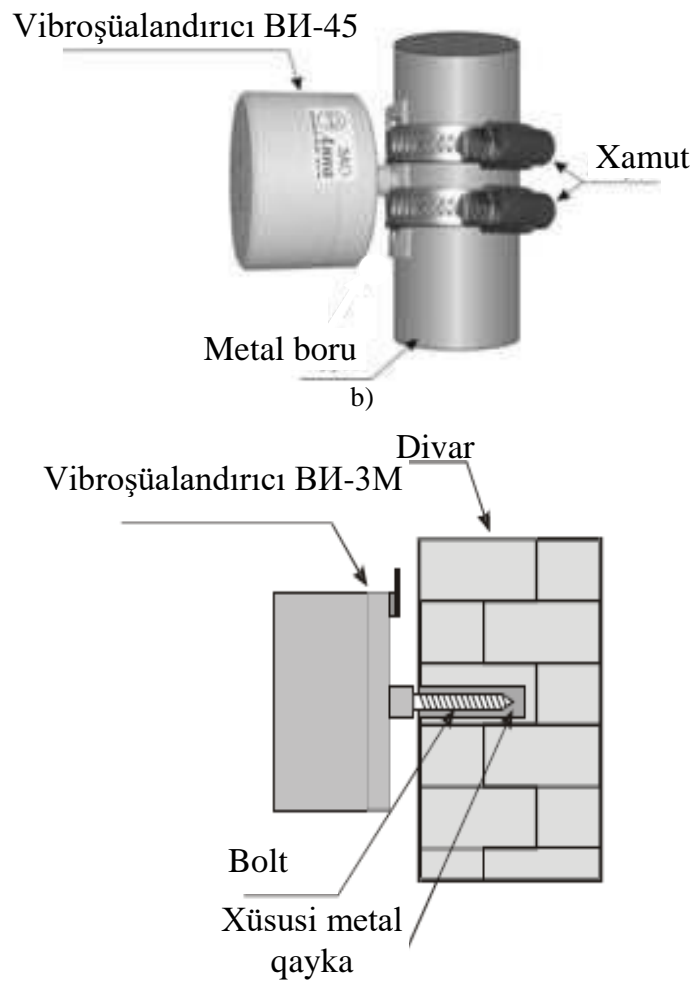

c)

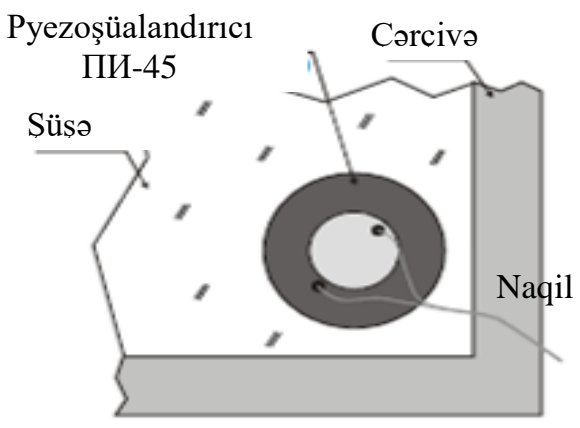

d)

Şəkil 2. Otağın kommunikasiya və konstruktiv elementlərində vibroküy dalğalarının yaradılması

a) vibroküyləyici qurğu "Sonata-AB", b) metal boruda, c) divarda, d) pəncərə şüşəsində vibroküy dalğalarının yaradılması

Səs dalğaları enerjisinin konstruksiyalarda yaratdığı udulan tərkibinin intensivliyinin azaldılması məqsədilə bu konstruksiyaların səthini səsuducu əmsalı böyük olan və yuxarıda qeyd edilən məsaməli üzlük materiallardan da istifadə edilə bilər.

Lakin bir çox hallarda danışıq iştirakçıları, o cümlədən dəvət edilənlər müasir miniatür yazma qurğularından (ardınca, diktofon) istifadə etməklə nitq informasiyasını gizli yazmaqla əldə edə bilərlər. $\mathrm{Bu}$ məqsədlə rəqib miniatür radioötürücü qurğu vasitəsilə nitq siqnallarını otaqdan xaricdə yerləşdirilmiş radioqəbuledici qurğulara ötürə bilər. Ötürmə üçün radio/optik (infraqırmızı tezlik diapazonlu dalğalarla), elektromaqnit və $\mathrm{s}$. kanallardan istifadə etmək olar. Başqa bir halda qurğunun miniatür mikrofon və radioötürücü hissəsini stolda, stulda, otağın digər əşyalarında və ya özünə aid əşyalarda (qələmində, qeyd dəftərində, eynəyində və s.) gizlətmək, yazma hissəsini isə bədənində yerləşdirmək olar. Diktofonun bədəndə (geyimdə) gizlədilməsi halından daha çox istifadə olunur.

Praktikada danışıq iştirakçılarının diktofondan istifadə edilməsinin və ya yazıların üçüncü tərəfə verilməsinin yolverilməz olması barədə şifahi və yazılı razılaşmaların pozulması halları daha geniş yayılmışdır. Ona görə də danışıqların məxfiliyinin qorunmasının on etibarlı yolu onların yazılması imkanının aradan qaldırılmasıdır. $\mathrm{Bu}$ imkan, işi müxtəlif prinsiplərə əsaslanan texniki vasitələrlə həyata keçirilir. Burada, yalnız danışıqların diktofonla gizli yazılması və bir neçə mühafizə metodları nəzərdən keçirilir. Qeyd edək ki, hal-hazırda köhnə tip maqnit kasetli analoq diktofonlardan demək olar ki, istifadə edilmədiyindən mətndə yazma qurğusu dedikdə nitq informasiyasının yazılması üçün sərt disklər, Smart Media, Memory Stick kimi daşıyıcılarla təchiz edilmiş miniatür rəqəmsal diktofonlar nəzərdə tutulur.

Otaqda gedən danışıqların icazəsiz (gizli) yazılmasının qarşısının alınması əsasən iki istiqamətdə aparılır:

- yazma qurğusunun otağa gətirilməsinin aşkarlanması və kənarlaşdırılması;

- otağa gətirilmiş diktofonların yazılarının maskalanmasi.

Burada maskalanma dedikdə səs (nitq) dalğalarının akustik yayılma mühitinin küy siqnalları ilə qarışdırmaqla yazıların güclü təhrifə uğradılması prosesi başa düşülür. Təhrifə uğradılmış nitq yazıları dinlənilmə rejimində anlaşılmaz səs yazıları kimi (küy kimi) qavranır: mövcud texniki üsullarla nitqi küydən (maneələrdən) ayırmaq mümkün olmur.

Mühafizə metodu kimi ilk növbədə danışıq iştirakçılarının özləri ilə diktofon gətirməsinin aşkarlanması prosesi həyata keçirilir. Bu məqsədlə metal detektorlardan (metal aşkarlayan qurğu), radio lokatorlardan, rentgenoskopiya aparatlarından və diktofon aşkarlayan xüsusi təyinatlı digər qurğulardan istifadə edilir. Bu qurğuların bəziləri diktofonu ancaq işlək rejimdə, digərləri isə passiv rejimdə (söndürülmüş halda) aşkarlayır və bir qayda olaraq müəssisənin girişində və ya danışıqlar aparılan otaqların qap1 keçidlərində çərçivələr formasında, görünməz şəkildə quraşdırılır. Qurğular təşkilatın mühafizə xidməti tərəfindən idarə edilir. Daha ciddi mühafizə tədbiri kimi mobil aşkarlayıcılar vasitəsilə dəvətlilərin geyimi, çantası və $\mathrm{s}$. əşyaları yoxlanıla bilər (etik qaydalar gözlənilməklə).

İşləyən diktofonun aşkarlanması onun şüalandırdığı elektromaqnit dalğalarının aşkarlanıb (qəbul edilib) identifikasiya edilməsinə, iş rejimində olmayanların aşkarlanması isə, məsələn, iştirakçılar istiqamətində müəyyən intensivlikli yüksək tezlikli dalğaların şüalandırılmasına və əks edilən dalğaların analizinə əsaslanır. Bu qurğuların qiyməti çox bahadır və yüksək səviyyəli tədbirlər zamanı istifadə edilir. Çatışmayan cəhəti şüaların yüksək dozasının insan orqanizmi üçün ziyanlı təsirə malik olmasıdır. Ziyanı azaltmaq məqsədilə dalğaların intensivliyini azaltmaq lazım gəlir ki, bu halda aşkarlayıcı (lokator) yoxlanılan obyektə 2-5 $\mathrm{sm}$. yaxınlaşdırılmalıdır. Qeyd olunan texniki vasitələrin heç biri 


\section{“Informasiya tohlükosizliyinin aktual multidissiplinar elmi-praktiki problemlori” V respublika konfransı, 29 noyabr 2019-cu il}

diktofonun 100\% aşkarlanmasını təmin etmir. Digər tərəfdən danışıqların məxfilik səviyyəsi yüksək deyilsə yoxlanmanın aşkar şəkildə aparılması etik normalar baxımından qəbuledilməz sayıla bilər. Ona görə də bir çox hallarda nitq informasiyanın təhlükəsizliyi məqsədilə ikinci sinif qurğulardan - yazılışı təhrif edən qurğulardan daha geniş istifadə edilir.

$\mathrm{Bu}$ qurğularda yazını təhrifə uğratma vasitəsi kimi elektromaqnit və akustik küy siqnallarından istifadə edilir və təsir mexanizminə görə:

- diktofonun informasiya daşıyıcısının (yaddaş elementinin);

- mikrofonun;

- diktofonun elektron sxem dövrəsinin (radioelektron elementlərinin) normal işinin pozulmasına imkan yaradan qurğular qruplarına bölünür [5].

Elektromaqnit küy maneəsinin təsir mexanizmi aşağıdakı kimidir: elektron generatoru sxemi ifrat yüksək tezlikli (IYT) və kifayət qədər gücə malik (3-5 vatt) elektromaqnit dalğaları (1 QHs ətrafında) şüalandırır. $\mathrm{Bu}$ şüalar mikrofon gücləndiricisinin sxemində və digər sxem dövrələrində parazit küy siqnalları yaradaraq onların normal iş rejimlərini pozur və nəticədə yazılmış səslər güclü təhrifə uğrayaraq dinlənilərkən anlaşıllmır. Küy mənbəyinə yaxın məsafədə yerləşən diktofonun sxem dövrəsinin metal hissələrində, məsələn, korpusda yaranan fuko cərəyanlarının təsiri ilə radioelementlərin yol verilən həddən artıq q1zması nəticəsində sıradan çıxma halı da baş verə bilər .

$\mathrm{Bu}$ metod otağa gətirilmiş diktofonların harada gizlədilməsinin (iştirakçılarda, şəxsi və ya otaq əşyalarında və s.) məlum olmadığı hallarda xüsusilə effektlidir. Lakin bu metodun da bir sıra çatışmayan cəhətləri var. IYYT küy siqnalları intensivliyə və təsir müddətinə görə yol verilən həddi (dozanı) keçdikdə insan orqanizmi üçün müəyyən təhlükə törədə bilər. Digər bir nöqsanı antenasının dar şüalanma istiqamətli (60-70 dərəcə əhatəli) olmasıdır, yəni danışıqlar stolu ətrafında oturan bütün iştirakçıları əhatə etməsi üçün bir neçə antenadan istifadə edilməsi zərurəti yarana bilər.

İkinci qrup qurğular generasiya etdikləri akustik küy səsləri ilə diktofonun normal işinə əngəl yaratma prinsipinə (akustik küyləmə prinsipi) əsaslanır və əsasən iki alt qrupa bölünür:

- ultrasəs diapazonunda maneə küy siqnallarının yaradilması;

- eşidilən səs diapazonunda maneə küy siqnallarının yaradilması.

Birinci qrup qurğularda akustik küy siqnalı kimi eşidilməyən diapazonlu ultrasəs siqnallarından (20-22 kHs) istifadə edilir. $\mathrm{Bu}$ siqnallar diktofonun gücləndiricisinin amplitud-tezlik xarakteristikasını dəyişərək onun normal yazı rejiminə mane olur. Mikrofonun korpusunun metal materialdan olması (ekranlanması) ehtimalını nəzərə alaraq küy siqnallarının intensivliyini artırmaq lazım gələ bilər. Bu qrup qurğuların (məsələn, VNG 012-U Savesa) təhlükəsizliyi mühafizə səviyyəsi yüksəkdir.
İkinci qrup qurğularda eşidilən səs diapazonlu tezliklərdə a) "nitqəbənzər" (bir neçə nitq fraqmentlərinin qarışı ğından alınan səs) küy siqnalları; b) "ağ" küy (səs diapazonunda intensivliyi bərabər paylanan küy siqnalları) və ya c) "narıncı" küy (səs diapazonunda, tezliyin artması istiqamətində, hər növbəti oktava zolağında intensivliyi $3 \mathrm{db}$ azalan səs siqnalları) səsləri yayan generatorlardan istifadə edilir [6]. Danışıqlar bu küy səslərinin fonunda aparılır. Küy səsinin intensivliyi elə seçilir ki, qulağın nitqi küy səsindən ayırmaq xüsusiyyəti öz təsirini itirməsin. Küy səsi ilə nitq səsi qarışığı kiçik ölçülü ucadan danışanlardan səsləndirilir. Çıxış gücü əllə tənzimlənən ("ANG-2000", "Kabinet") və danışı səslərinin intensivliyindən asılı olaraq avtomatik tənzimlənən ("Барон", "Шopox-1") olmaqla iki variantda hazırlanır. Sadə və ucuz olmaqla istənilən tip mikrofonun işini əngəlləyir. Bu qrupa daxil olan qurğuların ümumi çatışmayan cəhəti informasiya təhlükəsizliyi tədbirinin aşkar aparılmasıdır. Digər çatışmayan cəhət tədbir təşkilatçıları tərəfindən danışıqların texniki vasitələrlə həyata keçirdikləri yazılışların anlaşıqlıq və fərdi tembr (ahəng) göstəricilərinin pisləşməsidir [7].

\section{NəTİCO}

Məqalədə akustik kanallarla ötürülən nitq informasiyasının (danışıqların) təhlükəsizliyi məsələləri və mühafizə metodları araşdırılır. Mühafizə predmeti otaq daxilində aparılan danışıqlardır. Danışıqların gizli əldə edilməsinin iki variantına baxılır: tədbir iştirakçılarının diktofonla danışıqları gizli yazması və danışıqların bərpası məqsədilə akustik sızma kanalları ilə xaricə yayılan vibroakustik siqnalların qəbulu. Nitq informasiyasının akustik sızma kanalları kimi a) xaricdən danışıqların bilavasitə dinlənilməsinə imkan yaradan konstruktiv elementlər (giriş qapısı, havalandırma sistemləri, kommunikasiya xətlərinin otaqdan çıxış yerləri ilə divar arasındakı boşluqlar və s.); b) vibrosızma kanalları - pəncərə şüşələri, su, qaz, isitmə sistemlərinin metal boru xətləri, divarlar və s. konstruktiv elementlər nəzərdə tutulur. Qeyd olunan kanallarla nitq informasiyasının gizli əldə edilməsinin qarşısını alan mühafizə metodları, bu metodlar əsasında yaradılmış bəzi texniki qurğular və onların iş prinsipləri izah edilir. Təşkilat rəhbərləri aparılan danışıqların konfidensiallıq dərəcəsindən, otağın inşaat-konstruktiv xüsusiyyətlərindən, maliyyə imkanlarından və s. amillərdən asılı olaraq nitq informasiyasının təhlükəsizliyini təmin etmək məqsədilə məqalədə qeyd edilən təklif və tövsiyələrdən istifadə edə bilərlər.

\section{İSTINADLAR}

[1] Теоретические основы физической акустики, http://userdocs.ru/fizika/4987/index.html

[2] Dövlət sirri haqqinda AR Qanunu, http://www.e-qanun.az/framework/3731

[3] Vladimir V. Grishachev, "Detecting Threats of Acoustic Information Leakage through Fiber Optic Communications," Journal of Information Security, 2012, №3, pp. 149-155.

[4] Система виброакустической и акустической защиты. "Соната-АВ". Руководство по эксплуатации, http://www.cbi-info.ru/files/sonata-av3m.pdf

[5] Каргашин В. Л, “Защита от утечки речевой информации из помещений. Практические аспекты реализации," http://www.bnti.ru/showart.asp?aid=1024\&lvl=04.02.03. 


\section{“Informasiya tohlükosizliyinin aktual multidissiplinar elmi-praktiki problemlori” V respublika konfransı, 29 noyabr 2019-cu il}

[6] ГОСТ 12.1.003-83 (СТ СЭВ 1930-79). Шум. Общие требования безопасности.

[7] L Reva, V. A. Trushin, A. A. Ivanov, T. V. Borbotko, "Truthfulness of estimation of voice information protection from leakage through technical canals," Journal of Physics: Conference Series, Vol. 803, No. 1, p. 012128, 2017

ON SOME VIBRO-ACOUSTIC METHODS FOR PROTECTING VOICE INFORMATION TRANSMITTED THROUGH ACOUSTIC CHANNELS

Bikas Aghayev $^{1}$, Tarlan Aliyev ${ }^{2}$, Kovsar Aliyeva ${ }^{3}$, Maleyka Ibisova ${ }^{4}$ Institute of Information Technology of ANAS, Baku, Azerbaijan 1,2,3,4depart6@iit.sciense.az
Annotation - The article explores the security of speeches in the room and provides confidential information. Participants are looking at ways of securing speech information transmitted through acoustic channels with a tape recorder and protecting the initial state of vibroacoustic signals leaking out of the room. Proposals are provided for the cases under consideration to determine the organization's information security policy.

Keywords - speech information; acoustic distribution channel; secret record of negotiations; vibroacoustic leakage channels; information security; protection of speech information 